\title{
Modulation of Very Low Density Lipoprotein Production and Clearance Contributes to Age- and Gender-dependent Hyperlipoproteinemia in Apolipoprotein E3-Leiden Transgenic Mice
}

\author{
Bart J.M. van Vlijmen, ${ }^{\star}$ H. Belinda van 't Hof, ${ }^{\star}$ Marc J.T.M. Mol, ${ }^{\ddagger}$ Hans van der Boom, ${ }^{\star}$ André van der Zee, ${ }^{\S}$ Rune R. Frants, ${ }^{\S}$ \\ Marten H. Hofker, ${ }^{\S}$ and Louis M. Havekes* \\ *TNO Prevention and Health, Gaubius Laboratory, Leiden; ${ }^{\ddagger}$ Department of Medicine, Division of General Internal Medicine, University \\ Hospital Nijmegen, 6500 HB Nijmegen; ${ }^{\S}$ Department of Human Genetics, Leiden University, 2301 CE Leiden, The Netherlands
}

\begin{abstract}
Apolipoprotein E3-Leiden (APOE*3-Leiden) transgenic mice have been studied to identify factors modulating chylomicron and VLDL remnant lipoprotein metabolism. Transient elevated levels of VLDL/LDL-sized lipoproteins occurred in these mice with maximal levels during the period of rapid growth (optimum at $\mathbf{4 5} \mathrm{d}$ of age). After about $100 \mathrm{~d}$ of age, serum cholesterol and triglyceride levels stabilized to slightly elevated levels as compared to control mice. The expression of the APOE*3-Leiden transgene was not age-dependent. In young mice the in vivo hepatic production of VLDL-triglycerides was $50 \%$ increased as compared to older mice. This is sustained by in vivo VLDL-apo B turnover studies showing increased (75\%) VLDL-apo B secretion rates in young mice, whereas the VLDL-apo B clearance rate appeared not to be age dependent.

On a high fat/cholesterol diet, females displayed significantly higher cholesterol levels than males (10 versus 7.0 $\mathrm{mmol} /$ liter, respectively). Serum levels of VLDL/LDL sized lipoproteins increased upon administration of estrogens, whereas administration of testosterone gave the opposite result. As compared to male mice, in female mice the hepatic VLDL-triglyceride production rate was significantly elevated. Injection of estrogen in males also resulted in increased VLDL-triglyceride production, although not statistically significant. In vivo VLDL-apo B turnover experiments showed that the VLDL secretion rate tended to be higher in females. Although, the fractional catabolic rate of VLDLapo $B$ is not different between males and females, administration of estrogens in males resulted in a decreased clearance rate of VLDL, whereas administration of testosterone in females resulted in an increased clearance rate of VLDL. The latter presumably due to an inhibiting effect of testosterone on the expression of the APOE*3-Leiden transgene.

We conclude that hyperlipidemia in APOE*3-Leiden transgenic mice is strongly affected by age via its effect on hepatic VLDL production rate, whereas gender influences hyperlipidemia by modulating both hepatic VLDL produc-
\end{abstract}

Address correspondence to L.M. Havekes, TNO-PG, Gaubius Laboratory, P.O. Box 2215, 2301 CE Leiden, The Netherlands. Phone: 3171-5181449; Fax: 31-71-5181904; E-Mail: lm.havekes@pg.tno.nl

Received for publication 11 December 1995 and accepted in revised form 15 December 1995.

J. Clin. Invest.

(C) The American Society for Clinical Investigation, Inc. 0021-9738/96/03/1184/09 \$2.00

Volume 97, Number 5, March 1996, 1184-1192 tion and clearance rate. (J. Clin. Invest. 1996. 97:11841192.) Key words: familial dysbetalipoproteinemia $\bullet$ transgenic mice $\bullet$ age $\bullet$ gender $\bullet$ sex hormones

\section{Introduction}

In Western society people spend most of their life span under nonfasting conditions. As a result, there is a continuous release into the circulation of newly synthesized intestinal and hepatic lipoproteins, i.e., chylomicrons and VLDL lipoproteins. Normally, the remnants of these lipoproteins are rapidly removed from the circulation via receptor-mediated uptake in the liver. Apo $\mathrm{E}$ is a structural component of these remnant lipoproteins and serves as a ligand in the receptor mediated uptake by the liver $(1,2)$. In patients suffering from familial dysbetalipoproteinemia (FD), ${ }^{1}$ a defective apo E leads to impaired hepatic uptake of remnant lipoproteins (1). The consequent accumulation of these lipoproteins leads to a predisposition of these patients to coronary and/or peripheral atherosclerosis $(1,3)$.

Several in vivo and in vitro studies have demonstrated the unequivocal role of apo $\mathrm{E}$ in remnant lipoprotein metabolism $(4,5)$. However, in homozygous carriers of the mutant APOE*2(Arg158 $\rightarrow$ Cys) allele, the presence of binding defective apo E2 does not explicitly result in the accumulation of remnant lipoproteins. Obviously, other environmental or genetic factors interfere with remnant metabolism (1).

In humans, heterozygosity for the rare mutant APOE*3Leiden allele is also associated with an accumulation of remnant lipoproteins due to an impaired remnant clearance, despite the presence of normal apo E (6). Thus, in carriers of the apo E3-Leiden mutation, FD is inherited in a dominant fashion although also in this case, additional environmental and genetic factors do modulate the severity of the disease.

Because of heterogeneity in environmental and genetic background, these additional factors can hardly be studied in humans. Therefore, to elucidate subtle factors that may modulate the metabolism of remnant lipoproteins, a suitable experimental animal model is required. Experimental animals, like inbred mice and rats, efficiently remove remnant lipoproteins, even under severe dietary stress conditions (7) and are thus less suitable for these studies. Recently, we reported that transgenic mice expressing the human APOE*3-Leiden mutation also demonstrate a hyperlipidemic phenotype (8). Furthermore, in these mice, severe hyperlipidemia was observed after feeding high fat/cholesterol-containing diets which positively correlated with the level of expression of the transgene

1. Abbreviations used in this paper: FCR, fractional catabolic rate; FD, familial dysbetalipoproteinemia; HFC, high fat/cholesterol; SR, secretion rate. 
(9). In addition, on high fat/cholesterol-containing diets the high expressing lines developed atherosclerotic lesions of which the severity was positively correlated with serum levels of cholesterol-rich remnant lipoproteins. Thus, also in these transgenic mice apo E3-Leiden behaves like a dominant trait in the accumulation of remnant lipoproteins.

We reasoned that $\mathrm{APOE} * 3-$ Leiden mice display a defect in plasma clearance of remnant lipoproteins which allows us to study the effect of more subtle factors involved in remnant metabolism under highly standardized conditions. The present study shows that in APOE*3-Leiden transgenic mice the plasma level of VLDL remnants is strongly influenced by age and gender related factors. Age appeared to affect the hepatic VLDL production rate, whereas gender modulates both the VLDL production and clearance rate.

\section{Methods}

Animals. Transgenic mice of line No. 2, heterozygous for the expression of the human APOE*3-Leiden and human APOC1 gene, were used (8). Transgenic and nontransgenic littermates were obtained by breeding with C57BL/6J mice (The Broekman Institute bv, Someren, The Netherlands). Mice of the F5 and F6 generation were included in the trials. Transgenic mice were identified by sandwich ELISA for the presence of human apo $\mathrm{E}$ in the serum (for method see below). Immediately after weaning (at age $25 \mathrm{~d}$ ) mice were equally divided into two groups, consisting of female and male transgenic or nontransgenic mice. One group of mice was fed a regular mouse diet (SRM-A; Hope Farms, Woerden, The Netherlands), and the other group of mice was fed a semisynthetic high fat/cholesterol (HFC) diet. This HFC diet is a basic semisynthetic diet, which was composed essentially according to Nishina et al. (7), supplemented with cocoa butter $(15 \%$, by wt) and cholesterol $(0.25 \%$, by wt) and was purchased from Hope Farms. Mice were housed under standard conditions in conventional cages and given free access to food and water. None of the transgenic or nontransgenic mice were lost during the study.

Lipid and lipoprotein analysis. After a 12-h fasting period, mice were weighed and $\sim 50 \mu \mathrm{l}$ of blood was obtained from each individual mouse through tail bleeding. Blood samples were taken at different time points as indicated in the figures for both diets. Total serum cholesterol and triglyceride levels (without measuring free glycerol) were measured enzymatically using commercially available kits (No. 236691; Boehringer Mannheim, Mannheim, Germany and No. 337-B; Sigma Chemical Co., St. Louis, MO).

For size fractionation of lipoproteins, some $200 \mu \mathrm{l}$ of pooled serum (from at least 12 mice), was injected onto a $25 \mathrm{ml}$ Superose $6 \mathrm{~B}$ column (Pharmacia Fine Chemicals, Uppsala, Sweden) connected to an HPLC pump system and eluted at a constant flow rate of $0.5 \mathrm{ml} /$ min with PBS, $\mathrm{pH}$ 7.4. The effluent was collected in $0.5-\mathrm{ml}$ fractions. Cholesterol and triglyceride concentrations in lipoprotein fractions were measured enzymatically, using kits No. 236691 and 701904 (Boehringer Mannheim), respectively.

Human Apo E3-Leiden protein measurements. Human apo E concentrations were measured by sandwich ELISA. Affinity purified polyclonal goat anti-human apo $\mathrm{E}$ antibodies were used for coating. Affinity purified polyclonal rabbit anti-human apo $\mathrm{E}$ antibodies were used as second antibodies. Thereafter, the plates were incubated with swine anti-rabbit IgG antibodies conjugated to horseradish peroxidase. Finally, horseradish peroxidase detection was performed using horseradish peroxidase substrate tetramethylbenzidine. Pooled plasma from healthy human subjects with known apo E level, was used as a standard.

Human apo E and mouse Ldlr mRNA measurements in the liver. Total RNA was isolated from liver using the RNAZOL procedure (Cinna/Biotecx, Houston, TX). RNA samples (10 $\mu \mathrm{g}$ per lane) were separated by electrophoresis through a denaturing agarose gel $(1.2 \%$ $\mathrm{wt} / \mathrm{vol}$ ) containing $7.5 \%$ formaldehyde and transferred to a nylon membrane (Hybond N+; Amersham Corp., Arlington Heights, IL) according to the manufacturer's recommendations. For analysis of the mouse $L d l r$ expression, polyA ${ }^{+}$RNA was isolated using the PolyATtract mRNA isolation kit (Promega Corp., Madison, WI). Blots were subsequently hybridized with ${ }^{32} \mathrm{P}$-labeled probes of human apo E cDNA (10), mouse $L d l r$ cDNA (mLDLRc90) (11), and rat glyceraldehyde-3-phosphate dehydrogenase (GAPDH) cDNA at $55^{\circ} \mathrm{C}$ in a solution containing $50 \%$ formamide. The intensity of the hybridization signal was quantified with a PhosphorImager (Molecular Dynamics Inc., Sunnyvale, CA). The amounts of APOE*3-Leiden and LDL receptor mRNA were related to the level of GAPDH mRNA.

Hormone treatment. HFC-fed male and female transgenic mice 14 wk of age were injected subcutaneously along the back every $14 \mathrm{~d}$ with testosterone decanoate or estradiol decanoate dissolved in arachis oil. Blood sampling and serum analysis were performed before and after $28 \mathrm{~d}$ of hormone treatment as described above. Estradiol decanoate and testosterone decanoate were a kind gift from Drs. $\mathrm{H}$. Verheul and F. Deckers, Organon International bv., Oss, The Netherlands.

In vivo hepatic triglyceride production. After a 12-h fasting period mice were injected intravenously with Triton WR1339 (500 mg/ $\mathrm{kg}$ body wt) (12) using $15 \%$ (wt/vol) Triton solution in $0.9 \% \mathrm{NaCl}$. At 0,45 , and $90 \mathrm{~min}$ after injection blood samples were drawn and analyzed for triglycerides as described above. Production of hepatic triglyceride was calculated from the slope of the curve and expressed as $\mathrm{mmol} / \mathrm{h}$ per $\mathrm{kg}$ body wt. For calculation of mouse total serum volume we used the equation: serum volume $=0.33 \times$ body $w t(13)$.

Isolation and labeling of $V L D L$. Blood was collected from six to eight fasted transgenic or 15-20 fasted nontransgenic mice. Sera were pooled and ultracentrifuged to obtain the VLDL fraction $(\mathrm{d}<1.006$ $\mathrm{g} / \mathrm{ml}$ ). VLDL cholesterol and triglyceride were determined enzymatically as described above, and VLDL protein was determined using the method of Lowry et al. (14). To determine apo B content of the VLDL, some $25 \mu \mathrm{g}$ of VLDL protein was subjected to a 4-20\% gradient SDS-PAGE. After staining with Coomassie brilliant blue R and destaining in $30 \%$ methanol $/ 10 \%$ acetic acid the gels were scanned using an HP ScanJet Plus, Hewlett Packard, Santa Clara, CA, and the amount of apo $\mathrm{B}(100+48)$ relative to total protein was calculated. The percentage of total apo B ranged from 20 to $40 \%$ of total VLDL protein. VLDL was radiolabeled with ${ }^{125} \mathrm{I}$ by the iodine monochloride method (15). The fraction of ${ }^{125} \mathrm{I}$-label present in apo B was determined by isopropanol precipitation $(16,17)$ and ranged from 30 to $65 \%$.

In vivo removal of ${ }^{125} I$-labeled $V L D L$-apo $B$. Fasted mice were intravenously injected with $0.2 \mathrm{ml}$ of $0.9 \% \mathrm{NaCl}$ containing BSA $(1 \mathrm{mg} / \mathrm{ml})$ and $10 \mu \mathrm{g}$ of ${ }^{125} \mathrm{I}$-labeled VLDL. Blood samples of $\sim 25 \mu \mathrm{l}$ were collected from the tail vein at $\mathrm{t}=1,3,5,10,30,60$, and $90 \mathrm{~min}$ after injection. The serum content of ${ }^{125}$ I-labeled apo B was measured by isopropanol precipitation followed by counting ${ }^{125}$ I-label. A biexponential model was used to estimate the area under the ${ }^{125} \mathrm{I}$-apo $\mathrm{B}$ decay curve and subsequent calculation of VLDL-apo B kinetics. VLDL secretion rate was calculated from VLDL fractional catabolic rate and serum apo B pool. Since $>85 \%$ of serum apo B and triglycerides were associated with the $\mathrm{d}<1.006$ lipoprotein fraction, we determined the serum apo B pool by measuring serum triglyceride levels $48 \mathrm{~h}$ before injection and the apo $\mathrm{B}$ to triglyceride ratio in the isolated $\mathrm{d}<1.006$ lipoproteins (VLDL) of mice from the same group (autologous). Serum triglycerides on $48 \mathrm{~h}$ before injection were $\sim 20 \%$ higher as compared to serum triglyceride levels at the end of the turnover experiment. However, this decreasing effect was similar for all mice injected.

\section{Results}

Effect of age, gender, and diet on serum lipid and lipoprotein levels. The increase in body weight with age for male and female transgenic and nontransgenic mice is shown in Fig. 1. No 
A

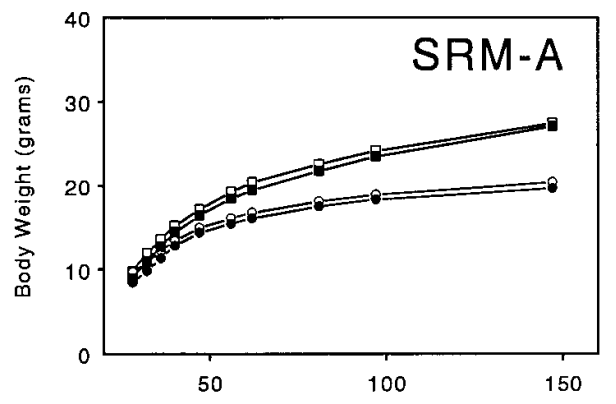

B

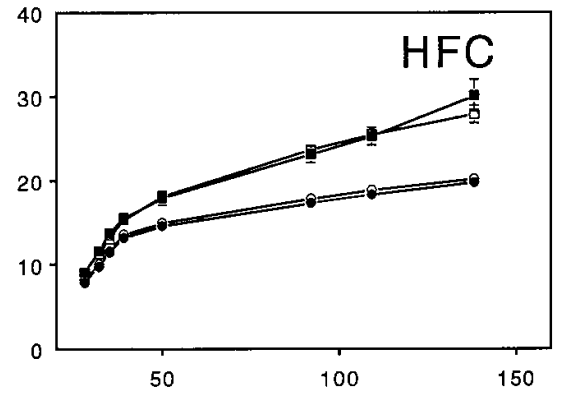

Figure 1. Age- and sex-dependent body weight. Body weight changes due to the increase in age were followed over time in male (squares) and female (circles) mice fed an SRM-A diet $(A)$ or an HFC diet $(B)$. All groups contain at least 13 mice, which were weaned at day $25 \pm 1$. Body weight was determined after an overnight fast. Values are expressed as mean $\pm \mathrm{SE}$ (error bar not visible when $\mathrm{SE}<$ symbol size). Closed symbols, APOE*3-Leiden transgenic mice; open symbols, control mice.

difference in growth rate was observed between transgenic and control mice and between both diets administered. At an early age, the gain in body weight was more rapid than at later age and more pronounced for male than for female mice.

Fig. $2(A-C)$ shows the effect of age on serum cholesterol $(A)$, triglyceride $(B)$, and the apo E3-Leiden protein levels $(C)$ for SRM-A fed mice. At weaning, transgenic and nontransgenic animals showed comparable levels of serum cholesterol and triglycerides. Transgenic animals showed a rapid significant increase $(P<0.01)$ in both serum cholesterol and triglycerides with a maximum around $45 \mathrm{~d}$ of age. This postweaning increase was more pronounced for male than for female trans- genic mice. Serum apo E3-Leiden levels also displayed a significant increase $(P<0.01)$ in levels directly after weaning. However sex differences were not observed during this period. At an early age nontransgenic animals also showed an increase for both serum cholesterol and triglyceride levels, however this increase was less pronounced as compared to transgenic animals.

The increases at an early age in transgenics in levels of cholesterol, triglycerides, and apo E3-Leiden appeared to be transient. After $150 \mathrm{~d}$ of age, serum cholesterol and triglycerides had decreased to almost basal levels of about 2.5 and 2.0 $\mathrm{mmol} /$ liter, respectively. At this age females had higher levels of cholesterol and triglycerides than males. In addition, fe-
A
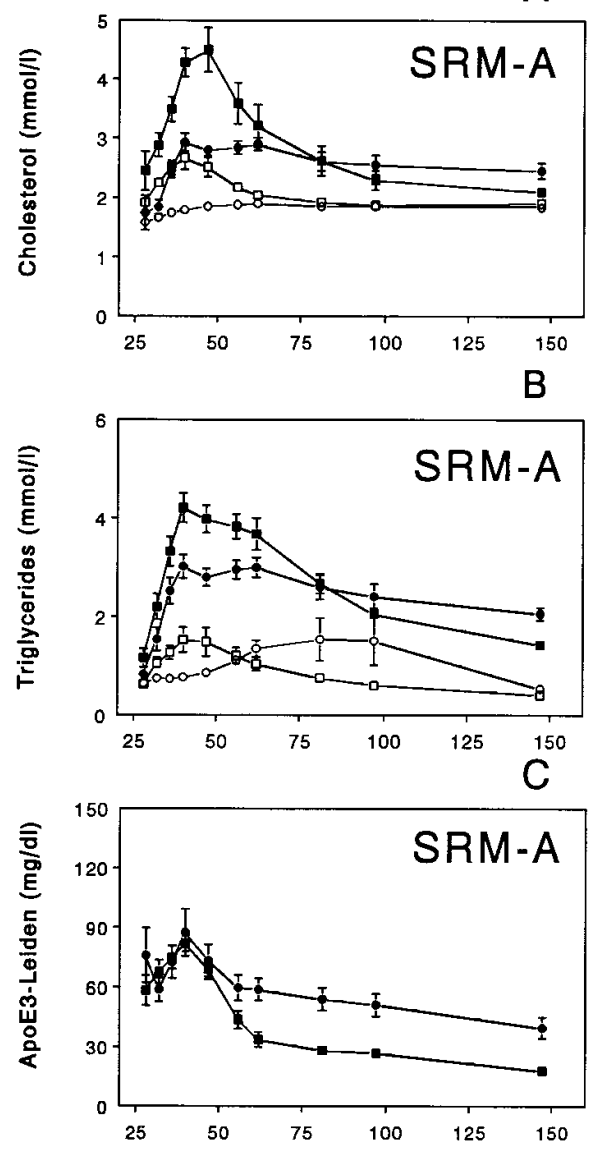
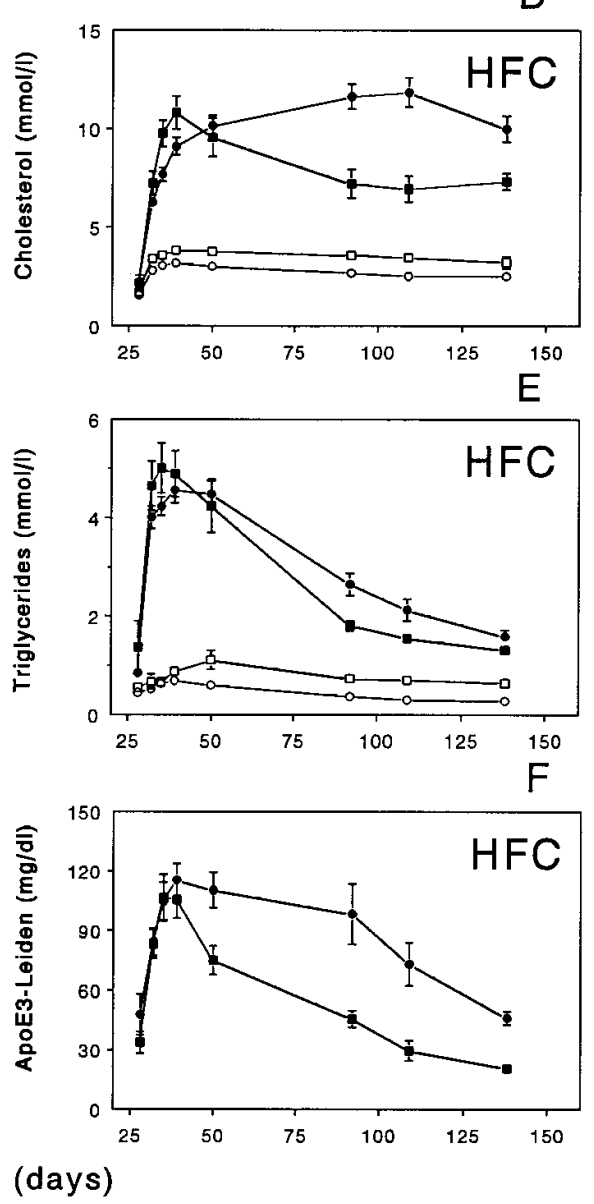

Figure 2. Age- and sex-dependent serum cholesterol, triglycerides and apo E3-Leiden levels. Mice were fed an SRM-A diet $(A-C)$ or an HFC diet $(D-F)$. Serum cholesterol $(A$ and $D)$, triglycerides $(B$ and $E)$, and apo E3-Leiden levels $(C$ and $F$ ) were followed in time in male (squares) and female (circles) APOE*3-Leiden and control mice. All groups contain at least 13 mice, which were weaned at day $25 \pm 1$. Blood samples were drawn by tail bleeding after an overnight fast. Vertical bars represent standard error of the means. Statistical analysis was performed using the repeated measuring ANOVA to determine the influence of age and gender on cholesterol, triglycerides and apo E3-Leiden levels. Closed symbols, APOE3-Leiden mice, open symbols, control mice. 
males showed significantly higher apo E3-Leiden levels than males (40 vs $18 \mathrm{mg} / \mathrm{dl}$ ).

Fig. $2(D-F)$ shows the serum cholesterol, triglyceride, and apo E3-Leiden levels after feeding a cholesterol-rich HFC diet. The time course profiles for serum triglycerides $(E)$ resembled those observed after regular SRM-A feeding (B), whereas after feeding HFC the respective levels of apo E3Leiden $(F)$ were about twice as high as during SRM-A feeding $(C)$. At an early age, serum cholesterol levels $(D)$ were two to threefold higher as compared to SRM-A feeding. In contrast to SRM-A feeding, HFC feeding led to prolonged elevated levels of cholesterol, although for males a slight decrease in serum cholesterol levels to about $7.0 \mathrm{mmol} /$ liter was observed at a later age.

Nontransgenic animals at an early age also showed increased levels of cholesterol and triglycerides after feeding HFC diet, but to a much smaller extent as compared to transgenic animals. In contrast to transgenic mice, nontransgenic male mice at a later age had slightly higher lipid levels as compared to nontransgenic females.

Fig. 2 suggests that the effect of HFC feeding on lipid levels at an early age is a result of both age, as observed during SRM-A feeding, and an additional dietary component. To study the effect of HFC feeding on serum lipid levels solely, mice of $200 \mathrm{~d}$ of age and fed a SRM-A diet were switched to the HFC diet. As illustrated in Fig. $3 \mathrm{~A}$, transgenic animals displayed an increase in serum cholesterol levels but less pronounced than at an early age (as shown in Fig. 2), and again the females were more responsive than the males (up to 7.5 and $5.5 \mathrm{mmol} / \mathrm{liter}$, respectively). Remarkably, serum triglycerides $(B)$ showed only a small and transient increase, whereas apo E3-Leiden levels $(C)$ strongly increased from 7 to 26 and from 30 to 90 for
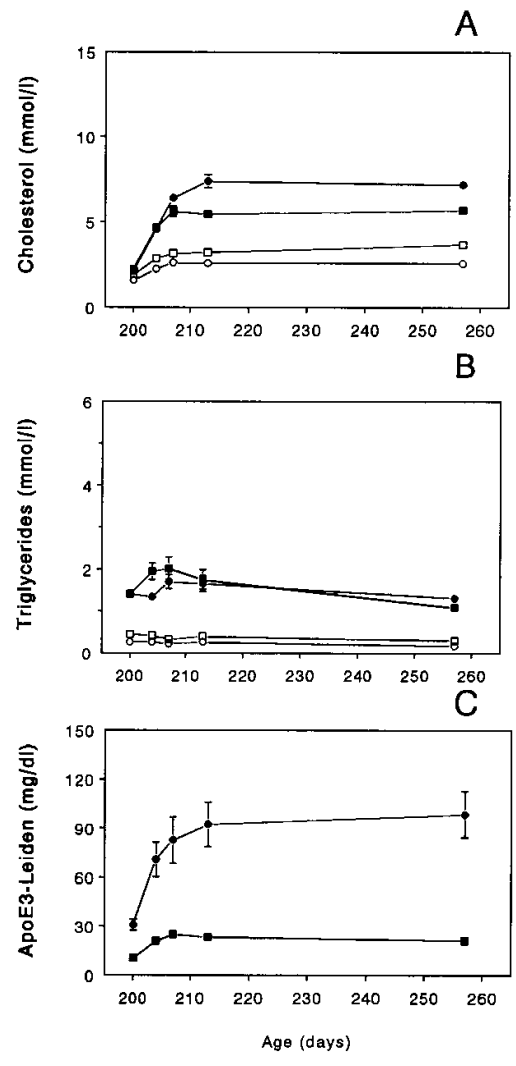

Figure 3. The effect of HFC feeding at a later age. Serum cholesterol $(A)$, triglycerides $(B)$, and apo E3-Leiden $(C)$ were followed in time for male (squares) and female (circles) mice which switched from SRM-A diet to HFC at $200 \mathrm{~d}$ of age. All groups contain at least 13 mice. Blood samples were drawn by tail bleeding after an overnight fast. Vertical bars represent SEMs. Statistical analysis was performed using the repeated measuring ANOVA to determine the influence of age and gender on cholesterol, triglycerides and apo E3-Leiden levels. Black symbols, APOE3Leiden mice; open symbols, control mice. males and females, respectively. In nontransgenics, serum cholesterol levels were much less severely elevated after feeding HFC diet at a later age, whereas serum triglyceride levels were not affected at all.

The results described above clearly indicate that serum lipids in transgenic mice are affected by age, nutrition, and gender. To investigate in which lipoprotein classes these changes in serum lipids mainly occur, we analyzed lipoprotein profiles by FPLC gelpermeation chromatography using a Superose $6 \mathrm{~B}$ column and calculated the distribution of cholesterol among VLDL/LDL and HDL-sized lipoproteins, respectively. Feeding both an SRM-A or HFC diet, the major changes in serum cholesterol were confined to the VLDL/LDL-sized fractions. In addition, the higher serum cholesterol levels in females as compared to males during the diets at a later age are also confined to this lipoprotein fraction (results not shown).

We further investigated the effect of age and gender on hyperlipoproteinemia in the APOE*3-Leiden mice, separately. For investigating the effect of age we used only young ( $45 \mathrm{~d}$ of age) and older ( $>100 \mathrm{~d}$ of age) SRM-A fed male mice, since the effect of age on serum lipid levels was more pronounced in male than in female mice. For studying the effect of gender we used older male and female mice $(>100 \mathrm{~d}$ ) fed an HFC diet, since the effect of gender on hyperlipoproteinemia was more pronounced in older than in young mice.

Effect of age on VLDL metabolism in vivo. Our previous study has shown that the level of hyperlipidemia corresponds to the expression level of the APOE*3-Leiden gene $(8,9)$. To study whether the transient accumulation of VLDL/LDL sized lipoproteins at an early age on either diet is due to transient higher expression levels of the transgene, we determined APOE*3-Leiden mRNA in the liver by Northern blotting. Livers of mice with maximum hyperlipidemia (45 d of age) were compared to older mice ( $>100 \mathrm{~d}$ of age). From the results presented in Table I, it is obvious that no significant differences in E3-Leiden mRNA levels in the liver were observed between young and old male mice when fed a SRM-A diet. Feeding HFC diet resulted in slightly but not significantly elevated levels of E3-Leiden mRNA as compared to SRM-A feeding. These results indicate that the age-dependent serum lipid and apo E3-Leiden protein levels were not related to changes in expression of the transgene.

To investigate whether the effect of age on serum levels of

Table I. Age- and Diet-dependent APOE*3-Leiden $m R N A$ Expression in Mouse Liver

\begin{tabular}{ccccc}
\hline Sex & Age & SRM-A & & HFC \\
\hline \multirow{4}{*}{ Males } & $d$ & & $\%$ & \\
& 45 & $100.0 \pm 19.0$ & & $118.2 \pm 12.6$ \\
& $>100$ & $80.9 \pm 5.6$ & & $117.2 \pm 24.7$
\end{tabular}

APOE*3-Leiden RNA in liver was quantified for young (45 d of age) and old male mice ( $>100 \mathrm{~d}$ of age). After an overnight fast, mice were anesthesized, liver was excised, and APOE*3-Leiden RNA was quantified as described in methods section. Mice were fed SRM-A diet or HFC diet. APOE*3-Leiden RNA concentrations are relative to internal standard GAPDH and expressed as a percentage of male (45 d of age) SRM-A fed group. Values are the mean \pm SD of three to five mice. Values are not statistically different $(P<0.05$; using nonparametric MannWhitney test). 
VLDL/LDL-lipoproteins was related to changes in endogenous VLDL production by the liver we determined the in vivo hepatic VLDL-triglyceride production rate. Therefore, young male mice of $45 \mathrm{~d}$ of age and old male mice ( $>100 \mathrm{~d}$ of age), both transgenic and nontransgenic, were injected with Triton WR1339 and the increase in serum triglycerides after injection was determined. As presented in Table II, VLDL-production rates were significantly affected by age, young male mice displaying about $50 \%$ higher VLDL-triglyceride production rate than older mice irrespective of the presence of the APOE*3Leiden transgene.

To investigate whether the effect of age on serum levels of VLDL/LDL-lipoproteins was also due to changes in VLDL clearance rate, in vivo VLDL turnover studies were performed. Young male transgenic and nontransgenic mice of 45 $\mathrm{d}$ of age and old male transgenic mice ( $>100 \mathrm{~d}$ of age), were injected with $10 \mu \mathrm{g}$ of autologous ${ }^{125}$ I-labeled VLDL, and the ${ }^{125} \mathrm{I}$-apo $\mathrm{B}$ disappearance from the circulation was determined. As illustrated in Fig. $4 A$ and presented in Table III, VLDL fractional catabolic rate (FCR) was clearly affected by transgene expression. Young transgenic mice displayed a significantly lower VLDL-FCR as compared to young nontransgenic mice. In contrast, no effect of transgene expression on VLDL secretion rate (VLDL-SR) was observed, indicating that the higher serum lipid levels in transgenic mice as compared to nontransgenic mice were due to an impaired VLDL clearance rate, as expected.

An age-related change in VLDL-FCR was not observed as young and old transgenic mice displayed comparable VLDLFCR (Fig. $4 B$ and Table III), In contrast, a strong and significant effect of age on VLDL-SR is observed (Table III, 4.24 versus $2.45 \mu \mathrm{g}$ apo $\mathrm{B} / \mathrm{h}$ per $\mathrm{g}$ body wt in young and old transgenic mice, respectively). This decreasing VLDL-SR with age corresponds with the observed lower hepatic VLDL-triglyceride production rate as determined by the Triton method (Table II).

Effect of sex hormones on serum lipid levels and on VLDL metabolism in vivo. Maximal gender related differences in lipid levels in APOE*3-Leiden mice were observed at a later age $(>100 \mathrm{~d})$ after feeding HFC. Thus, to investigate these gender related differences, older mice on an HFC diet were treated with either testosterone or estradiol. Mice were in-

Table II. Age-dependent In Vivo Hepatic VLDL-Triglyceride Production

\begin{tabular}{ccc}
\hline & \multicolumn{2}{c}{ VLDL-triglyceride production rate } \\
\cline { 2 - 3 } Age & non-transgenics & transgenics \\
\hline$d$ & \multicolumn{2}{c}{ mmol/h/kg body weight } \\
45 & $0.180 \pm 0.021^{*}$ & $0.150 \pm 0.011^{*}$ \\
$>100$ & $0.112 \pm 0.017$ & $0.102 \pm 0.018$ \\
\end{tabular}

After an overnight fast SRM-A fed male mice were injected with Triton WR1339 (see Methods section). The serum triglycerides were determined just before injection ( $0 \mathrm{~min}$ ) and at 45 and $90 \mathrm{~min}$ after Triton injection. Production of hepatic triglyceride rate was calculated from the slope of the curve and is expressed as $\mathrm{mmol} / \mathrm{h} / \mathrm{kg}$ body weight. Values are expressed as mean $\pm \mathrm{SD}(n=4) . * P<0.05$, indicating the difference between mice of $45 \mathrm{~d}$ of age and mice of $>100 \mathrm{~d}$ of age, using nonparametric Mann-Whitney test.

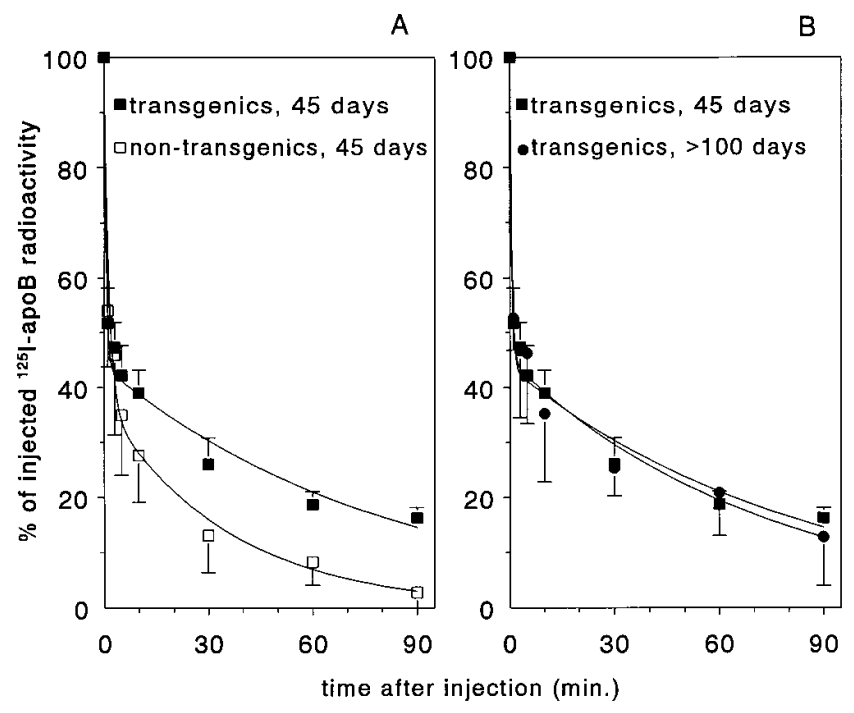

Figure 4. The effect of age on VLDL-apo B removal. SRM-A fed male mice were injected with autologous ${ }^{125}$ I-labeled VLDL. $25 \mu \mathrm{l}$ of blood was drawn at each time point and ${ }^{125} \mathrm{I}$-apo $\mathrm{B}$ radioactivity of the serum sample was measured. Values are the mean \pm SD of seven mice. Curves were calculated from the mean data using a bi-exponential curve fit model.

jected subcutaneously either a physiological or a pharmacological dose of either hormone. As presented in Table IV, in male mice, treatment with estradiol resulted in a significant increase in serum triglyceride levels, whereas treatment with testosterone decreased serum cholesterol levels, although not significantly. Also for female mice, treatment with estradiol resulted in significantly increased serum triglyceride levels, whereas treatment with a pharmacological dose of testosterone significantly decreased both serum cholesterol and triglyceride levels.

To investigate in which lipoprotein classes these changes in serum lipid levels mainly occur, we generated lipoprotein profiles by FPLC gelpermeation chromatography using Superose 6B. In male mice (Fig. $5 A$ ) treatment with estradiol resulted in a slight dose-dependent decrease of HDL cholesterol, whereas an increase of cholesterol in the VLDL-sized lipoprotein fractions is observed, thus, leading to an unaffected total serum cholesterol level as presented in Table IV. The decrease in se-

Table III. Age-dependent VLDL-apoB Fractional Catabolic Rates and Secretion Rates

\begin{tabular}{lccc}
\hline \multicolumn{1}{c}{ Mice } & Age & FCR & SR \\
\hline & $d$ & pools $/ h$ & $\mu g$ apoB $/ \mathrm{h} /$ g body $w t$ \\
nontransgenics & 45 & $3.94 \pm 1.22$ & $3.67 \pm 1.81$ \\
transgenics & 45 & $1.45 \pm 0.34^{*}$ & $4.24 \pm 0.95$ \\
transgenics & $>100$ & $2.00 \pm 1.23$ & $2.45 \pm 1.05^{\ddagger}$ \\
& & & \\
\hline
\end{tabular}

After an overnight fast SRM-A fed male mice were injected with $10 \mu \mathrm{g}$ of autologous ${ }^{125}$-labeled VLDL protein. ${ }^{125} \mathrm{l}$-apo B disappearance from the circulation was determined and FCR and SR were calculated (see Methods). Values are expressed as mean $\pm \mathrm{SD}(n=7)$. ${ }^{*} P<0.05$, indicating the difference between transgenic and nontransgenic mice of age $45 \mathrm{~d},{ }^{\ddagger} P<0.05$, indicating the difference between transgenic mice of 45 $\mathrm{d}$ of age and $>100 \mathrm{~d}$ of age, using nonparametric Mann-Whitney test. 
Table IV. Serum Lipid Concentrations after 4 wk of Hormone Treatment of APOE*3-Leiden Transgenic Mice

\begin{tabular}{|c|c|c|c|}
\hline Sex & Treatment & $\mathrm{TC}$ & TG \\
\hline & & \multicolumn{2}{|c|}{$\mathrm{mmol} /$ liter } \\
\hline \multirow[t]{5}{*}{ Males } & Placebo & $6.20 \pm 1.20$ & $2.37 \pm 0.39$ \\
\hline & $\begin{array}{l}\text { Estradiol decanoate } \\
\quad(20 \mu \mathrm{g} / \text { mouse })\end{array}$ & $5.47 \pm 0.66$ & $3.06 \pm 0.60 *$ \\
\hline & $\begin{array}{l}\text { Estradiol decanoate } \\
\quad(100 \mu \mathrm{g} / \text { mouse })\end{array}$ & $6.71 \pm 0.32$ & $4.57 \pm 0.65^{*}$ \\
\hline & $\begin{array}{l}\text { Testosterone decanoate } \\
\quad(250 \mu \mathrm{g} / \text { mouse })\end{array}$ & $5.45 \pm 0.32$ & $2.49 \pm 0.65$ \\
\hline & $\begin{array}{l}\text { Testosterone decanoate } \\
\quad(1250 \mu \mathrm{g} / \text { mouse })\end{array}$ & $5.18 \pm 0.75$ & $2.66 \pm 0.44$ \\
\hline \multirow[t]{5}{*}{ Females } & Placebo & $9.46 \pm 1.50$ & $3.36 \pm 0.79$ \\
\hline & $\begin{array}{l}\text { Estradiol decanoate } \\
\quad(20 \mu \mathrm{g} / \text { mouse })\end{array}$ & $10.70 \pm 1.72$ & $4.62 \pm 0.64 *$ \\
\hline & $\begin{array}{l}\text { Estradiol decanoate } \\
\quad(100 \mu \mathrm{g} / \text { mouse })\end{array}$ & $10.69 \pm 1.58$ & $5.09 \pm 0.73^{*}$ \\
\hline & $\begin{array}{l}\text { Testosterone decanoate } \\
(250 \mu \mathrm{g} / \text { mouse })\end{array}$ & $8.10 \pm 1.01$ & $2.47 \pm 0.55$ \\
\hline & $\begin{array}{l}\text { Testosterone decanoate } \\
\quad(1250 \mu \mathrm{g} / \text { mouse })\end{array}$ & $6.64 \pm 1.15^{*}$ & $2.26 \pm 0.33^{*}$ \\
\hline
\end{tabular}

TC, total cholesterol; TG, triglyceride. Total cholesterol and triglyceride values are the mean serum levels \pm SD of five APOE*3-Leiden transgenic mice per group. $* P<0.05$, indicating the difference between hormone and placebo treated groups of mice of the same sex, using nonparametric Mann-Whitney tests.

rum cholesterol and triglycerides levels observed after testosterone treatment of female mice was confined to VLDL/LDL sized-lipoprotein fractions (Fig. $5 \mathrm{~B}$ ).

To investigate whether changes in lipid levels after hormone treatment were initiated by changes in transgene expression, we also determined APOE*3-Leiden mRNA levels in the liver of both HFC-fed male and female mice, treated with either testosterone or estradiol. As presented in Table V, for

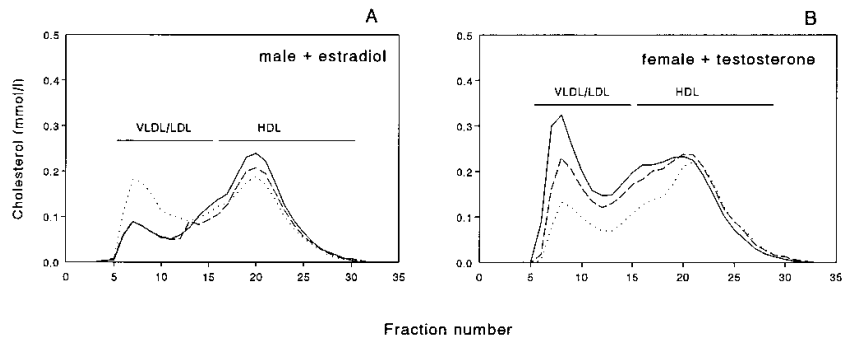

Figure 5. Distribution of serum cholesterol among lipoprotein fractions after hormone treatment. Lipoprotein fractions were separated by permeation chromatography using a $25-\mathrm{ml}$ Superose $6 \mathrm{~B}$ column as described in Methods. Lipoprotein profiles are shown for male $(A)$ and female transgenic mice $(B)$ which were treated with estradiol decanoate or testosterone decanoate, respectively. Each run is performed with a pool of at least five mice of the same group. Fraction numbers 5-15 and 16-30 correspond to VLDL/LDL and HDL, respectively. Solid, dashed, and dotted lines represent mice treated with placebo, physiological dose, and pharmacological dose of hormone, respectively (see Table IV).
Table V. Hepatic APOE*3-Leiden mRNA Levels after 4 wk of Hormone Treatment

\begin{tabular}{|c|c|c|}
\hline \multirow[b]{2}{*}{ Treatment } & \multicolumn{2}{|c|}{ APOE*3-Leiden mRNA } \\
\hline & Males & Females \\
\hline & \multicolumn{2}{|c|}{$\%$ of control } \\
\hline Placebo & $100.0 \pm 22.7$ & $100.0 \pm 9.6$ \\
\hline $\begin{array}{l}\text { Estradiol decanoate } \\
(20 \mu \mathrm{g} / \mathrm{mouse})\end{array}$ & $100.5 \pm 19.6$ & $98.8 \pm 12.5$ \\
\hline $\begin{array}{l}\text { Estradiol decanoate } \\
\quad(100 \mu \mathrm{g} / \text { mouse })\end{array}$ & $74.8 \pm 26.9$ & $105.4 \pm 3.4$ \\
\hline $\begin{array}{l}\text { Testosterone decanoate } \\
\quad(250 \mu \mathrm{g} / \text { mouse })\end{array}$ & $74.1 \pm 19.4 *$ & $94.7 \pm 13.2$ \\
\hline $\begin{array}{l}\text { Testosterone decanoate } \\
\quad(1250 \mu \mathrm{g} / \text { mouse })\end{array}$ & $65.3 \pm 15.5^{*}$ & $83.4 \pm 8.9 *$ \\
\hline
\end{tabular}

mRNA levels were measured in livers of mice treated, as described, for 4 wk. mRNA concentrations were relative to internal standard GAPDH and expressed as a percentage of placebo group (control) of the same sex. Values are the mean \pm SD of five mice. $* P<0.05$, indicating the difference between hormone and placebo treated groups of mice of the same sex, using nonparametric Mann-Whitney tests.

both males and females, estradiol administration had no significant effect on the expression of the APOE*3-Leiden gene. In contrast, administration of testosterone resulted in a significant lowering of APOE*3-Leiden mRNA levels for both male and female mice. In a parallel experiment untreated male mice (placebo) displayed significantly lower expression of the APOE*3-Leiden transgene than untreated female mice (69.0 \pm 14.5 versus $100 \pm 13.2 \%)$. Since hepatic LDL receptors are known to be regulated by estradiol administration, at least in rats (18-20) and humans (21), we also determined LDL receptor mRNA levels in estradiol-treated female mice. In female mice hepatic $L d l r$ mRNA levels were not affected by estradiol administration $(100 \pm 25.3$ versus $102 \pm 25.9 \%$ for placebo and estradiol treated animals, respectively).

We investigated whether the changes in serum levels of VLDL/LDL-sized lipoproteins upon sex hormone administration were related to a concurrent change in hepatic VLDL triglyceride production rate. As presented in Table VI, placebo-treated female mice displayed a significantly higher VLDL-triglyceride production rate as compared to placebotreated male mice. VLDL-triglyceride production rate in female mice did not change upon testosterone treatment, whereas a $20 \%$ increase in VLDL-triglyceride production rate was observed in males after estrogen treatment.

To evaluate whether sex hormones were also influencing the plasma clearance rate of VLDL, we performed in vivo VLDL turnover studies. Placebo-treated male and female mice displayed comparable VLDL-FCR's (Table VII). As illustrated in Fig. $6 A$ and presented in Table VII, VLDL-FCR in males decreased significantly after estrogen treatment, whereas a significant increase in VLDL-FCR was observed in females after testosterone treatment (Fig. $6 B$; Table VII). Opposite effects were observed for VLDL-SR: VLDL-SR in male mice increased after estrogen treatment, whereas a slight decrease in VLDL-SR is observed in female mice after testosterone treatment. In addition, placebo-treated female mice displayed a higher VLDL-SR as compared to placebo treated 
Table VI. In Vivo Hepatic VLDL-Triglyceride Production after 4 wk of Hormone Treatment of APOE*3-Leiden Transgenic Mice

\begin{tabular}{lcc}
\hline \multirow{2}{*}{ Treatment } & \multicolumn{2}{c}{ VLDL-triglyceride production rate } \\
\cline { 2 - 3 } & Males & Females \\
\hline & $\%$ of placebo treated males \\
Placebo & $100.0 \pm 33.0$ & $135.6 \pm 33.0^{*}$ \\
Estradiol decanoate & $119.6 \pm 38.6$ & $\mathrm{ND}$ \\
$\quad(100 \mu \mathrm{g} /$ mouse $)$ & & $135.1 \pm 32.5$ \\
Testosterone decanoate & $\mathrm{ND}$ & \\
$(1250 \mu \mathrm{g} /$ mouse $)$ & &
\end{tabular}

After an overnight fast hormone treated APOE*3-Leiden transgenic mice were injected with Triton WR1339 (see Methods). The serum triglycerides were determined just before injection $(0 \mathrm{~min})$ and at 45 and 90 min after Triton injection. Hepatic VLDL triglyceride production rate was calculated from the slope of the curve and is expressed as $\mathrm{mmol} / \mathrm{h} / \mathrm{kg}$ body wt. Values are the mean $\pm \mathrm{SD}$. Since two independent experiments are combined to increase the number of animals per groups $(n=14-16)$ values are expressed as a percentage of the hepatic VLDL triglyceride production in placebo treated male mice in the same experiment. ${ }^{*} P<0.05$, indicating the difference between male and female mice, using nonparametric Mann-Whitney test. ND; not determined.

male mice. Although these effects on VLDL-SR were not significant, these changes in VLDL-SR correspond with changes upon hormone treatment in serum lipid levels (Table IV) and in hepatic VLDL-triglyceride production rate (Table VI).

\section{Discussion}

In the present study we showed that hyperlipidemia in APOE*3-Leiden mice was severely affected by age (Figs. 2 and 3). At early age in the APOE*3-Leiden mice an enhanced production of hepatic VLDL was observed, whereas the plasma clearance of VLDL was not age dependent (Tables II and III). Apparently, since APOE*3-Leiden mice are unable to efficiently remove VLDL remnants from the circulation

Table VII. VLDL-apoB Fractional Catabolic Rates and Secretion Rates after 4 wk of Hormone Treatment of APOE*3-Leiden Transgenic Mice

\begin{tabular}{clcc}
\hline Sex & \multicolumn{1}{c}{ Treatment } & FCR & SR \\
\hline \multirow{5}{*}{ Males } & & pools $/ \mathrm{h}$ & $\begin{array}{c}\mu g \text { apoB } / \mathrm{h} / \mathrm{g} \\
\text { body } w t\end{array}$ \\
& Placebo & $1.06 \pm 0.27$ & $1.65 \pm 0.34$ \\
& Estradiol decanoate & $0.68 \pm 0.17 *$ & $1.94 \pm 0.48$ \\
Females & $\quad(100 \mu$ g/mouse $)$ & & \\
& Placebo & $1.11 \pm 0.20$ & $2.13 \pm 0.79$ \\
& Testosterone decanoate & $1.46 \pm 0.42 *$ & $1.94 \pm 0.41$ \\
& $\quad(1250 \mu \mathrm{g} / \mathrm{mouse})$ & &
\end{tabular}

After an overnight fast HFC fed mice were injected $10 \mu \mathrm{g}$ of autologous ${ }^{125} \mathrm{I}$-labeled VLDL protein. ${ }^{125} \mathrm{I}$-apoB disappearance from circulation was determined and FCR and SR were calculated (see Methods). Values are the mean \pm SD of 4-6 mice per group. $* P<0.05$, indicating the difference between hormone and placebo treated groups of mice of the same sex, using nonparametric Mann-Whitney tests.

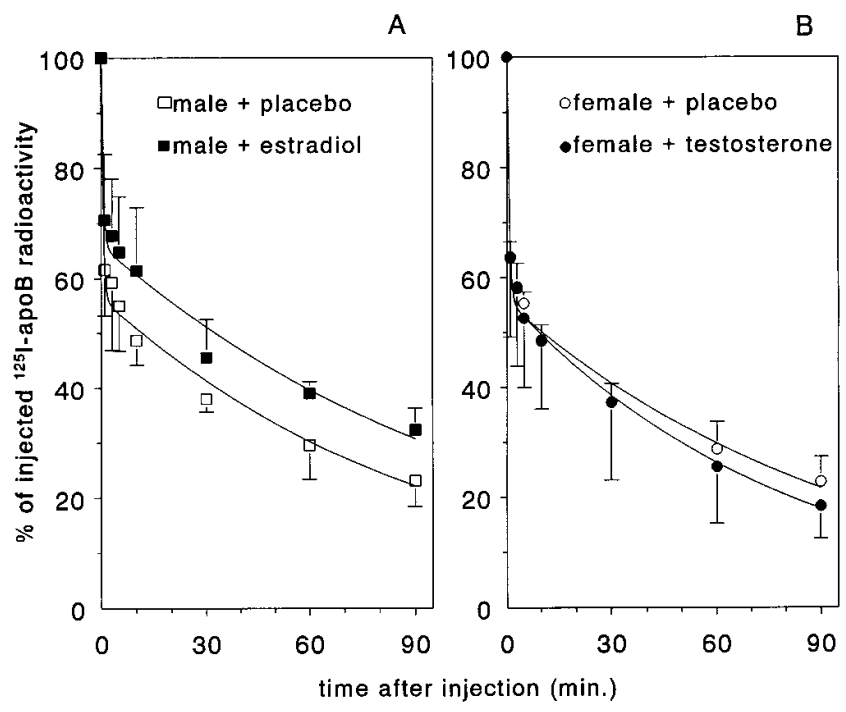

Figure 6. The effect of $4 \mathrm{wk}$ of hormone treatment on VLDL-apo B removal. HFC fed transgenic mice ( $>100 \mathrm{~d}$ of age) were injected with autologous ${ }^{125}$ I-labeled VLDL. Some $25 \mu$ l of blood was drawn at each time point and ${ }^{125} \mathrm{I}$-apo $\mathrm{B}$ radioactivity of the serum sample was measured. Values are the mean $\pm \mathrm{SD}$ of four to six mice. Curves were calculated from mean data using a bi-exponential curve fit model.

(Fig. $4 A$ and Table III), the extra supply of newly synthesized hepatic VLDL, as occurring during rapid growth, is primarily responsible for the enhanced accumulation of these lipoproteins in the plasma at young age. Increased VLDL production rate has also been reported to occur in young rapidly growing rats, due to a stimulation of the hepatic triglyceride synthesis by growth hormone $(22,23)$. In adult humans VLDL synthesis is also known to be stimulated upon body weight gain. Similar to $\mathrm{APOE}^{*} 3$-Leiden mice, in humans carrying mutant APOE alleles, like APOE*3-Leiden, APOE*2(Lys146 $\rightarrow$ Gln) and the APOE*2(Arg158 $\rightarrow$ Cys), high body weight and body weight gain are strong aggravating factors in the accumulation of VLDL remnants (familial dysbetalipoproteinemia) $(1,6,24)$.

APOE*3-Leiden transgenic mice displayed a marked effect of gender on the expression of hyperlipidemia (Figs. 2 and 3). Estrogens increase serum lipid levels, whereas testosterone showed the opposite effect (Table IV, Fig. 5). Previously, we reported that in APOE*3-Leiden mice the level of serum lipids is positively correlated with the level of the expression of the transgene in the liver (9). In the present study we found that expression of the APOE*3-Leiden gene results in a reduced clearance rate of VLDL, whereas the production of VLDL was not affected by the presence of the transgene (Table III). Thus, the observation that testosterone administration results in a reduced expression of the APOE*3-leiden transgene in the liver (Table V) can explain why testosterone administration resulted in lower serum VLDL/LDL lipoprotein levels, i.e., testosterone increases the clearance rate of VLDL, without an effect of testosterone on VLDL production rate (Table VI and VII). The reason for the effect of testosterone on the expression of the transgene is at present subject to speculation. Transgene expression was not affected by estrogen administration (Table V) and thus cannot explain the observed reducing effect of estrogen on VLDL clearance (Table VII). 
We present evidence that the increased serum lipid levels observed in females, and after estrogen administration in males (Table IV) can, at least partly, be explained by a relatively high rate of VLDL production (Table VI and VII).

The respective effects of both steroid hormones on the serum lipids and lipoprotein profile, hepatic VLDL triglyceride production and VLDL-apo B secretion are in line with the observed differences in lipid levels between untreated male and female APOE*3-Leiden mice. However, although both testosterone and estrogen treatment displayed considerable but opposing effects on VLDL clearance rate, differences in VLDL clearance were not found between untreated male and female mice. Similarly, although estrogens decreased VLDL clearance rate in males, the only significant difference between untreated males and females was increased VLDL production rate in females. These observations suggest discrepancies in the overall observed gender effect. However, in untreated males and females endogenous sex hormones form only part of the whole set of factors determining the final phenotype. The use of castrated males and ovariatectomized females instead of the respective sex hormone injected animals might have avoided these apparent discrepancies. In this study, addition of (supra) physiological doses of exogenous sex hormones was carried out only to evaluate the direction of the effect rather than that it aimed to extrapolate the effect to the basal in vivo situation in a quantitative sense.

Clearly, estrogens play an important role in mediating the gender differences observed in APOE*3-Leiden mice. The estrogen-mediated stimulation of hepatic VLDL production is well documented for humans (25) and rats (26) and suggests estrogen to be a risk factor for FD. Paradoxically, in humans FD is more prevalent in men than in women (1) and estrogenreplacement therapy is frequently used in reducing the expression of FD (27). Obviously, in humans estrogens play a protective rather than an aggravating role in the accumulation of VLDL remnant lipoproteins. An explanation for this beneficial effect of estrogens in humans is commonly assumed to be the fact that estrogens stimulate the expression of hepatic LDL receptors (18-21). The fact that an increase in hepatic LDL receptor mRNA upon estrogen treatment does not occur in hamsters and mice (28-30) including the present APOE*3Leiden transgenic mice, could explain the opposing effects of estrogen in humans and mice regarding the accumulation of remnants.

It could be possible that in mice hepatic LDL receptor activity is less susceptible to regulation than it is in humans. This is also supported by the observations that feeding C57BL/6J mice a high fat/cholesterol diet results in downregulation of HMG-CoA reductase activity whereas LDL receptor expression is relatively unaffected $(31,32)$. We hypothesize that an increased hepatic VLDL production increases the hepatic demand for cholesterol, but in mice this is not followed by upregulation of hepatic LDL receptors like in humans. Consequently, in APOE*3-Leiden mice, which are unable to efficiently metabolize hepatic lipoproteins, the increase in VLDL production upon the administration of estrogen will not be compensated by a simultaneous upregulation of LDL receptors and, thus, will lead to an extra accumulation of these lipoproteins in the plasma.

For the APOE*3-Leiden mice used in the present study, the APOC1 gene was included to be sure to have included an element that mediates liver-specific expression of the apo
E gene. Recently, we have generated transgenic mice expressing the APOE*3-Leiden gene without the human APOC1 gene but containing the hepatic control region mediating liver expression. These mice have comparable expression of the APOE*3-Leiden transgene on the level of mRNA and on the level of serum apo E protein. In addition, these mice display similar diet-induced hyperlipoproteinemia and also show a similar effect of age and gender on the hyperlipidemic phenotype (results not shown). Hence, a role for the human APOC1 gene in inducing the age- and sex-dependent hyperlipidemic phenotype can be excluded.

Transgenic mice expressing the defective APOE(Arg112, Cys142) variant, also display diet-induced elevated levels of plasma cholesterol and triglycerides due to the accumulation of remnant lipoproteins $(33,34)$. However, in these mice a similar gender- and age-related effect on plasma lipid levels has not been reported. On the contrary, in heterozygous apo E-deficient mice elevated plasma lipid levels in females as compared to males have also been observed, after being fed severe cholesterol-rich diets (35). Such a gender effect has not been reported (35-39) in homozygous apo E deficient mice, either due to the extreme phenotype of these mice under normal conditions or the absence of apo E itself.

In this study, we have shown that age- and gender-related changes in serum lipid levels of APOE*3-Leiden mice at least in part were related to mild changes in hepatic VLDL production. These results are consistent with our previous study (9) showing that the serum lipid levels in APOE*3-Leiden mice are also highly responsive to sucrose feeding which is known to increase hepatic lipogenesis and thereby the production and secretion of VLDL triglyceride by the liver $(7,40,41)$. We conclude that introducing a defective apo E, like in the APOE*3Leiden transgenic mice, leads to a high responsiveness of the serum lipid levels to relative mild changes in chylomicron and VLDL production rate. Consequently, this animal model can easily be used for studying the effect on plasma lipid levels of (subtle) environmental factors, like nutrition and drugs that are supposed to modulate VLDL production in the liver or lipid absorption and chylomicron production in the intestine. In addition, our results strongly sustain the hypothesis that in carriers of mutant apo $\mathrm{E}$ alleles the production rate of both liver and intestinal lipoproteins are important determinants of the clinical expression of familial dysbetalipoproteinemia.

\section{Acknowledgments}

We are grateful to Mrs. Marga M. van Eck for technical assistance and we would like to thank Dr. Ko Willems van Dijk for his helpful discussions.

This research was supported by the Netherlands Heart Foundation and the Netherlands Foundation of Scientific Research (projects 900-504-092 and 900-539-117). Dr. M. Mol is a recipient of a postdoctoral fellowship from the Royal Netherlands Academy of Arts and Sciences.

\section{References}

1. Mahley, R.W., and S.C. Rall. 1989. Type III hyperlipoproteinemia (dysbetalipoproteinemia): the role of apolipoprotein $\mathrm{E}$ in normal and abnormal metabolism. In The Metabolic Basis of Inherited Disease. C.R.Scriver, A.L. Beaudet, W.S. Sly, and D. Valle, editors. McGraw Hill Inc. New York. 1195-1213.

2. Mahley, R.W., T.L. Innerarity, S.C. Rall, Jr., K.H. Weisgraber, and J.M. Taylor. 1990. Apolipoprotein E: genetic variants provide insight into its structure and function. Curr. Opin. Lipid. 1:87-95. 
3. Havel, R.J., Y.-S. Chao, E. Windler, L. Kotite, and L.S.S. Guo. 1980. Isoprotein specificity in the hepatic uptake of apolipoprotein $\mathrm{E}$ and the pathogenesis of familial dysbetalipoproteinemia. Proc. Natl. Acad. Sci. USA. 77:43494353.

4. Sherill, B.C., T.L. Innerarity, and R.W. Mahley. 1980. Rapid hepatic clearance of the canine lipoproteins containing only the E apoprotein by a high affinity receptor. J. Biol. Chem. 255:1804-1807.

5. Mahley, R.W. 1988. Apolipoprotein E: cholesterol transport protein with expanding role in cell biology. Science (Wash. DC). 240:622-630.

6. de Knijff, P., A.M.J.M. van den Maagdenberg, A.F.H. Stalenhoef, J.A. Gevers Leuven, P.N.M. Demacker, L.P. Kuyt, R.R. Frants, and L.M. Havekes. 1991. Familial dysbetalipoproteinemia associated with apolipoprotein E3Leiden in an extended multigeneration pedigree. J. Clin. Invest. 88:643-655.

7. Nishina, P.M., J. Verstuyft, and B. Paigen. 1990. Synthetic low and high fat diets for the study of atherosclerosis in the mouse. J. Lipid Res. 31:859-869.

8. van den Maagdenberg, A.M.J.M., M.H. Hofker, P.J.A. Krimpenfort, I.H. de Bruijn, B.J.M. van Vlijmen, H. van der Boom, L.M. Havekes, and R.R. Frants. 1993. Transgenic mice carrying the apolipoprotein E3-Leiden gene exhibit hyperlipoproteinemia. J. Biol. Chem. 268:10540-10545.

9. van Vlijmen, B.J.M, A.M.J.M. van den Maagdenberg, M.J. Gijbels, H. van der Boom, H. HogenEsch, R.R. Frants, M.H. Hofker, and L.M. Havekes. 1994. Diet-induced hyperlipoproteinemia and atherosclerosis in apolipoprotein E3-Leiden transgenic mice. J. Clin. Invest. 93:1403-1410.

10. Zannis, V.I., J. McPherson, G. Goldberger, S.K. Krathanasis, and J.L. Breslow. 1984. Synthesis, intracellular processing, and signal peptide of human apolipoprotein E. J. Biol. Chem. 259:5495-5499.

11. Hoffer, M.J.V., M.M. van Eck, F. Pretrij, A. van der Zee, E. de Wit, D. Meijer, G. Grosveld, L.M. Havekes, M.H. Hofker, and R.R. Frants. 1993. The mouse low density receptor gene: cDNA sequence and exon-intron structure. Biochem. Biophys. Res. Commun. 191:880-886.

12. Otway, S., and D.S. Robinson. 1967. The use of a non-ionic detergent (Triton WR1339) to determine rates of triglyceride entry into the circulation of the rat under different physiological conditions. J. Biol. Chem. 244:4406-4412.

13. Bernstein, S.E. 1975. Physiological characteristics. In Biology of the Laboratory Mouse. 2nd ed. E.L. Green, editor. Dover Publications, Inc., New York. 337-350.

14. Lowry, O.H., N.J. Rosebrough, A.L. Farr, and R.J. Randall. 1951. Protein measurement with the Folin phenol reagent. J. Biol. Chem. 249:5133-5162.

15. Bilheimer, D.W., S. Eisenberg, and R.I. Levy. 1972. The metabolism of very low density lipoprotein proteins. I. Preliminary in vitro and in vivo observations. Biochim. Biophys. Acta. 260:212-221.

16. Kita, T., M.S. Brown, D.W. Bilheimer, and J.L. Goldstein. 1982. The metabolism of very low density and intermediate density lipoproteins with enhanced conversion to low density lipoprotein in WHHL rabbits. Proc. Natl. Acad. Sci. USA. 79:5693-5697.

17. Holmquist, L., K. Carlson, and L.A. Carlson. 1978. Comparison between the use of isopropanol and tetramethylurea for the solubilization and quantitation of human serum very low density apolipoproteins. Anal. Biochem. 88:457-460.

18. Kovanen, P.T., M.S. Brown, and J.L. Goldstein. 1979. Increased binding of low density lipoprotein to liver membranes from rats treated with $17 \alpha$-ethinyl estradiol. J. Biol. Chem. 254:11367-11373.

19. Chao, Y.-S., E.E. Windler, G.C. Chen, and R.J. Havel. 1979. Hepatic catabolism of rat and human lipoproteins in rats treated with $17 \alpha$-ethinyl estradiol. J. Biol. Chem. 254:11360-11366.

20. Windler, E.E.T., P.T. Kovanen, Y.-S. Chao, M.S. Brown, R.J. Havel, and J.L. Goldstein. 1980. The estradiol-stimulated lipoprotein receptor of rat liver. A binding site that mediates the uptake of rat lipoproteins containing apolipoproteins B and E. J. Biol. Chem. 255:10464-10471.

21. Angelin, B., H. Olivecrona, E. Reihner, M. Rudling, D. Stahlberg, M. Eriksson, S. Ewerth, P. Hendrikson, and K. Einarsson. 1992. Hepatic cholesterol metabolism in estrogen-treated men. Gastroenterology. 103:1657-1663.

22. Elam, M.B., C.P. Simkevich, S.S. Solomon, H.G. Wilcox, and M. Heim- berg. 1988. Stimulation of in vitro triglyceride synthesis in the rat hepatocyte by growth hormone treatment in vivo. Endocrinology. 122:1397-1402.

23. Elam, M.B., H.G. Wilcox, S.S. Solomon, and M. Heimberg. 1992. In vivo growth hormone treatment stimulates secretion of very low density lipoprotein by the isolated perfused rat liver. Endocrinology. 131:2717-2722.

24. Knijff, P., A.M.J.M. van den Maagdenberg, D.I. Boomsma, A.F.H. Stalenhoef, A.H.M. Smelt, J.J.P. Kastelein, A.D. Marais, R.R. Frants, and L.M Havekes. 1994. Variable expression of familial dysbetalipoproteinemia in apolipoprotein E*2(Lys146 $\rightarrow$ Gln) allele carriers. J. Clin. Invest. 94:1252-1262.

25. Walsh, B.W., I. Schiff, B. Rosner, L. Greenberg, V. Ravnikar, and F.M. Sacks. 1991. Effects of postmenopausal estrogen replacement on concentrations and metabolism of plasma lipoproteins. N. Engl. J. Med. 325:1196-1204.

26. Weinstein, I, F.C. Turner, C. Soler-Argilaga, and M. Heimberg. 1978 Effects of ethynyl estradiol on serum lipoprotein lipids in male and female rats. Biochim. Biophys. Acta. 530:394-401.

27. Stuyt, P.M.J., P.N.M. Demacker, and A. van 't Laar. 1986. A study of the hypolipidemic effect of estrogen in Type III hyperlipoproteinemia. Horm. Metab. Res. 18:607-610.

28. Srivastava, R.A.K., D. Baumann, and G. Schonfeld. 1993. In vivo regulation of low density receptors by estrogen differs at the post-transcriptional level in rat and mouse. Eur. J. Biochem. 216:527-538.

29. Himber, J., B. Missano, and H. Kuhl. 1994. Lack of effect on the low density lipoprotein receptor in hamsters treated with $17 \alpha$-ethinyl estradiol. Biochim. Biophys. Acta. 1211:359-363.

30. Tang, J., R.A.K. Srivastava, E.S. Krul, D. Baumann, B.A. Pfleger, R.T Kitchens, and G. Schonfeld. 1991. In vivo regulation of apolipoprotein A-I gene expression by estradiol and testosterone occurs by different mechanisms in inbred strains of mice. J. Lipid Res. 32:1571-1585.

31. Dueland, S., J. Drisko, L. Graf, D. Machleder, A.J. Lusis, and R.A. Davis. 1993. Effect of dietary cholesterol on 7 alpha-hydroxylase and hepatic LDL receptors in inbred mice. J. Lipid Res. 34:923-931.

32. Rudling, M. 1992. Hepatic mRNA levels for the LDL receptor and HMG-CoA reductase show coordinate regulation in vivo. J. Lipid Res. 33:493501

33. Fazio, S., Y.L. Lee, Z.S. Ji, and S.C. Rall, Jr. 1993. Type III Hyperlipoproteinemic phenotype in transgenic mice expressing dysfunctional apolipoprotein E. J. Clin. Invest. 92:1497-1503.

34. Fazio, S., D.A. Sanan, Y.-L. Lee, Z.-S. Ji, R.W. Mahley, and S.C. Rall, Jr. 1994. Susceptibility to diet-induced atherosclerosis in transgenic mice expressing a dysfunctional human apolipoprotein E(Arg 112,Cys142). Arterioscler. Thromb. 14:1873-1879.

35. van Ree, J.H., J.A.A. van den Broek, V.E.H. Dahlmans, P.H.E. Groot, M. Vidgeon-Hart, R.R. Frants, B. Wierenga, L.M. Havekes, and M.H. Hofker 1994. Diet-induced hypercholesterolemia and atherosclerosis in heterozygous apolipoprotein E-deficient mice. Atherosclerosis. 111:25-37.

36. Zhang, S.H., R.L. Reddick, J.A. Piedrahita, and N. Maeda. 1992. Spontaneous hypercholesterolemia and arterial lesions in mice lacking apolipoprotein E. Science (Wash. DC). 258:468-471.

37. Plump, A.S., J.D. Smith, T. Hayek, K. Aalto Setälä, A. Walsh, J.G. Verstuyft, E.M. Rubin, and J.L. Breslow. 1992. Severe hypercholesterolemia and atherosclerosis in apolipoprotein E-deficient mice created by homologous recombination in ES cells. Cell. 71:343-353.

38. Reddick, R.L., S.H. Zhang, and N. Maeda. 1993. Atherosclerosis in mice lacking apo E. Evaluation of lesional development and progression. Arterioscler. Thromb. 14:141-147.

39. Nakashima, Y., A.S. Plump, E.W. Raines, J.L. Breslow, and R. Ross. 1994. ApoE-deficient mice develop lesions of all phases of atherosclerosis throughout the arterial tree. Arterioscler. Thromb. 14:133-140.

40. Grundy, S.M., and M.A. Denke. 1990. Dietary influences on serum lipids and lipoproteins. J. Lipid Res. 31:1149-1172.

41. Witztum, J.L., and G. Schonfeld. 1978. Carbohydrate diet induced changes in very low density lipoprotein composition and structure. Diabetes. 27: 1215-1229. 